\title{
Introduction. The School: Its Genesis, Development and Significance
}

\author{
Urszula Wybraniec-Skardowska
}

\begin{abstract}
The Introduction outlines, in a concise way, the history of the LvovWarsaw School - a most unique Polish school of worldwide renown, which pioneered trends combining philosophy, logic, mathematics and language. The author accepts that the beginnings of the School fall on the year 1895, when its founder Kazimierz Twardowski, a disciple of Franz Brentano, came to Lvov on his mission to organize a scientific circle. Soon, among the characteristic features of the School was its serious approach towards philosophical studies and teaching of philosophy, dealing with philosophy and propagation of it as an intellectual and moral mission, passion for clarity and precision, as well as exchange of thoughts, and cooperation with representatives of other disciplines. The genesis is followed by a chronological presentation of the development of the School in the successive years. The author mentions all the key representatives of the School (among others, Ajdukiewicz, Leśniewski, Łukasiewicz, Tarski), accompanying the names with short descriptions of their achievements. The development of the School after Poland's regaining independence in 1918 meant part of the members moving from Lvov to Warsaw, thus providing the other segment to the name - Warsaw School of Logic. The author dwells longer on the activity of the School during the Interwar period - the time of its greatest prosperity, which ended along with the outbreak of World War 2. Attempts made after the War to recreate the spirit of the School are also outlined and the names of continuators are listed accordingly. The presentation ends with some concluding remarks on the contribution of the School to contemporary developments in the fields of philosophy, mathematical logic or computer science in Poland.
\end{abstract}

Mathematics Subject Classification (2000). Primary 01-02, 03-03.

Keywords. Lvov-Warsaw School, Twardowski, Warsaw School of Logic, Łukasiewicz, Leśniewski, Tarski, Lvov-Warsaw School Phenomenon, Polish logic after the War, Mostowski, Rasiowa, Grzegorczyk, Suszko. 


\section{A Short History and Influence of the School ${ }^{1}$}

\subsection{Twardowski's School. The Period of Crystallization of the L-WS}

The beginnings of the Lvov-Warsaw School (L-WS by acronym) date back to the end of the 19th century in Lvov, precisely to 1895, when Kazimierz Twardowski (1866-1938), who, at the age of 29 (in 1895), was appointed professor of philosophy in Lvov, then an Austrian town.

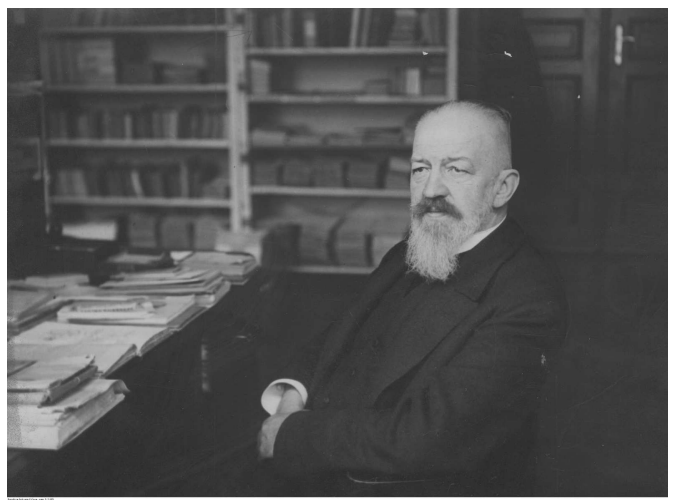

FiguRE 1. Kazimierz Twardowski.

Kazimierz Twardowski took the chair of Philosophy at Lvov University.

He came from Vienna, where he belonged to the last group of students of Franz Brentano. His main aim was to build and organize a strong philosophical circle in Poland, developing the scientific philosophy and methodology in the Brentano's spirit. Poland was at that time partitioned between Austro-Hungary, Germany and Russia; and Lvov belonged to the Austro-Hungarian Empire. Organizing regular and modern philosophical studies was not easy. In Lvov at that time there was no relevant library, or respectable philosophical studies; neither were there any philosophical seminars. Twardowski himself organized such a seminar and a library, donating his own book collection. His incredibly serious treatment of philosophical investigations and philosophy teachings consisting in promoting a clear and critical way of thinking and cultivating scientific, objective truth, his moral attitude towards philosophy in connection with his amazing charisma as a teacher and tutor, and friendly relations with students, were the main reasons of his becoming highly recognized by both students and reputable representatives of other fields of science, not only Lvov philosophy. Also his scientific-organizational achievements and ventures which he accomplished played a significant role. All

\footnotetext{
${ }^{1}$ Based on the entry from Stanford Encyclopedia of Philosophy 'Lvov-Warsaw School' elaborated by Jan Woleński [20], his famous book [21] and his article [22] and also the book edited by Jacek Jadacki and Jacek Paśniczek [7], the book by Jacek Jadacki [6] and the essay by Urszula Wybraniec-Skardowska [23].
} 
those features and abilities drew many young people towards philosophy, and their numbers began to grow quickly. Many of them became later Twardowski's devoted disciples. Twardowski promoted more than 30 Ph.D. students, who later earned their professorships not only in Poland, but also in various countries around the world, cultivating the tradition and the program of the School.

Among the characteristic features of the School was its serious approach towards philosophical studies and teaching of philosophy, dealing with philosophy and propagation of it as an intellectual and moral mission, passion for clarity and precision, as well as exchange of thoughts, cooperation with representatives of other disciplines at home and abroad, and also fruitful collaboration with mathematicians. The L-WS found its own scientific style of philosophizing and met international standards of training, rigor, professionalism and specialization. The Lvov-Warsaw School was the first of its kind in Poland. At the same time, its community managed to establish contacts between its philosophers and world philosophy.
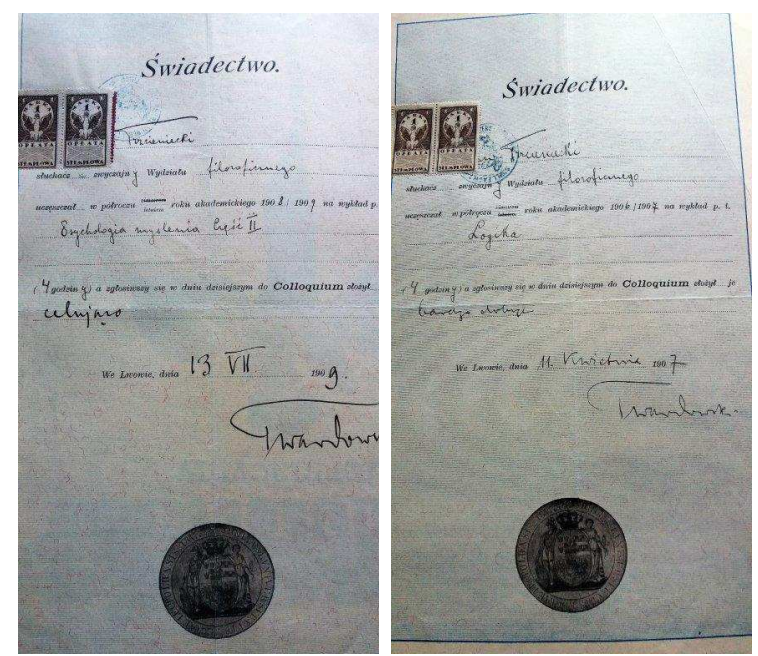

FiguRe 2. Student's certificates of Jan Trzciniecki from Lvov University Faculty of Philosophy, lectures in Psychology of Thinking and Logic, signed by Twardowski. ${ }^{2}$

In this philosophy program, logic - in its broader sense (formal logic, semantics and methodology of sciences) - was a meaningful element and although Twardowski was not a logician and was never a devotee of mathematical logic, he did lecture logic as well.

${ }^{2}$ Photos from the family archives of Irena Trzciniecka-Schneider. 
He credited Stanisław Piątkiewicz with forming the foundations of formal logic (then called logistics) in Poland, and recognized Lvov as the place of its birth.

The first students of Twardowski were Władysław Witwicki (1878-1948) and Jan Łukasiewicz (1878-1956). Both earned their Doctorates degrees under his supervision. Witwicki specialized in psychology. Eukasiewicz was Twardowski's first student to be interested in logic. After obtaining his PhD (1902) and the habilitation (1906), he systematically lectured logic (since 1906). The list of other, trained mainly by Twardowski, eminent individuals strongly interested in logic, who also attended courses conducted by Łukasiewicz include (in alphabetical order): Kazimierz Ajdukiewicz (1882-1963), Tadeusz Czeżowski (1889-1981), Tadeusz Kotarbiński (1886-1981), Zygmunt Zawirski (1882-1948) and Stanisław Leśniewski (1886-1939), who joined the group later, in 1910.

Twardowski promoted 30 full professors of different domains of science; he graduated many more PhD students.

Ajdukiewicz played an important role in logic at Lvov University. He also lectured for mathematicians (before Leon Chwistek got professorship in mathematical logic). Ajdukiewicz gave philosophy a clearly logicizing character.

Twardowski and Ajdukiewicz trained a group which included three women: Izydora Dąmbska (1904-1983), Seweryna Rohman (1904-1978), Maria Kokoszyńska (1905-1981); Henryk Mehlberg (1904-1978) and Zygmunt Schierer (1900?1943) also were a part of the group. One of the prominent listeners of Twardowski's and Ajdukiewicz's lectures was Eugenia Ginsberg-Blaustein (1905-1944) together with her husband Leopold Blaustein (1905-1944). They all belonged to the second generation of Twardowski's School. So did Janina Hosassion-Lindenbaum (later Mrs. Lindenbaum; 1899-1942), who was a philosopher, and a member of Kotarbiński's strong philosophical group.

The L-WS was also joined by a group of catholic philosophers, including Father Innocenty (Józef Maria) Bocheński (1902-1995) and Father Jan Salamucha (1904-1944).

All the representatives of the L-WS mentioned here are, in this book, classified to belong to the period of Crystallization (1900-1918). This period was terminated by the outbreak of the First World War, which interrupted regular scientific activities.

1.2. Warsaw School of Logic, its Main Figures and Ideas. The Period of prosperity The third generation of the students who later reached a great significance in developing the teachings and ideas of the L-WS consists essentially of well-known representatives of the so-called Warsaw School of Logic (by acronym - WSL), acting in the interwar period (1918-1939). In this book, the period is called the Prosperity period of the L-WS. It began when in 1916 the University of Warsaw was reactivated and Poland regained its independence in 1918. Leśniewski, Łukasiewicz, Kotarbiński and Wytwicki were offered as professors the University of Warsaw at that time. 
Many scholars from Lvov moved to Warsaw to organize and build national academic life. Twardowski's School ceased to be a school of Lvov and became a nationwide school. During the interwar period, his former students held chairs in philosophy departments at all of the Polish universities, with the exception of the Catholic University of Lublin.

The main centers of the L-WS since 1918 till 1939 were Lvov and Warsaw. It should be added that Lvov and Warsaw were also the two centers of the Polish mathematical school, which acted in parallel, but not independently of the L-WS. The cooperation of the Lvov-Warsaw philosophers with mathematicians evolved into establishing a logical school based in Warsaw (WSL).

Lvov was still a strong philosophical center, where under the influence of Twardowski, Ajdukiewcz and their disciples there was an exchange of ideas by representatives of various generations of the L-WS. Among the philosophical specialties there prevailed methodology of science and philosophy of language. Kotarbiński, who moved from Lvov to Warsaw in 1919, for the professorship, created a strong group of scholars working mainly in philosophy of science. Kotarbiński educated a whole pleiad of disciples in Warsaw, among others, Dina Sztejnbarg (later Mrs. Janina Kotarbińska; 1901-1997), Edward Poznański (1901-1976), and Aleksander Wundheiler (1902-1957) (the last two of them were the authors of the famous article on the concept of truth in physics).

Warsaw was mainly the center of logic. The development of logic in Warsaw was to a large extent the merit of the mathematician Zygmunt Janiszewski (1888-1920), belonging to the first generation of Twardowski's students, also vitally interested in logic and foundations of mathematics. He was one of the main initiators of the mutual cooperation between mathematicians and philosophers of Twardowski's School.

According to Janiszewski's program for development of mathematics, mathematical logic and foundations of mathematics had a great importance and played a special role. Logic in Lvov did not play such a role as it did in Warsaw. This happened mainly due to the fact that two philosophers, namely Łukasiewicz and Leśniewski, became professors of the University of Warsaw at the Faculty of Mathematical and Natural Sciences. They were put in charge of chairs in the mathematical environment and community at the Faculty (Eukasiewicz since 1915, Leśniewski since 1919).

The Warsaw School of Logic (WSL) grew out of Twardowski's School. The WSL had double roots: philosophical and mathematical. The combination of logic and philosophy in the history of the WSL did not limit itself to the fact that it was genetically related to philosophy. There was a close contact between its logicians and philosophers, in particular with Tadeusz Kotarbiński.

Stanisław Leśniewski and Jan Łukasiewicz, the WSL's two founders, and their student, Alfred Tarski, who obtained his doctor's degree in 1924 with an impressive scientific output, are the three outstanding representatives of the Warsaw School: 

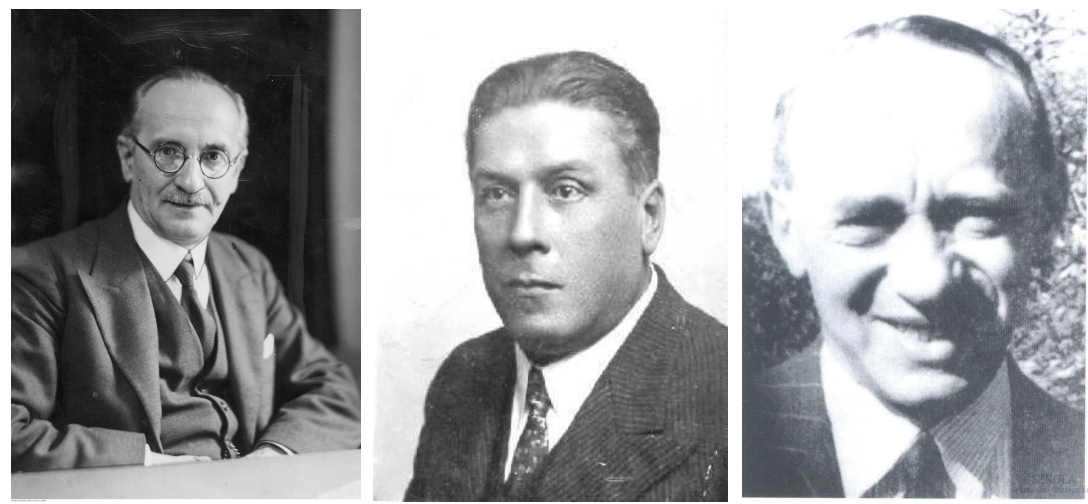

Figure 3. Jan Łukasiewicz, Stanisław Leśniewski and Alfred Tarski.

Łukasiewicz and Leśniewski were logicians and philosophers graduated at Lvov. They continued the philosophical thoughts, teaching methods and scientific research organization of Kazimierz Twardowski, but were protagonists of formal techniques in science, similar to those applied in mathematics. And the connection between philosophers and mathematics initiated by Janiszewski and his program for mathematical research manifested itself, among others, in the fact that Warsaw leading mathematicians (Wacław Sierpiński, Stefan Mazurkiewicz, Kazimierz Kuratowski) assigned a considerable role of logic to Jan Łukasiewicz and Stanisław Leśniewski, philosophers by educations. Both began teaching mathematical logic not only in the mathematical environment, but also in the philosophical one. Logic became an attractive subject to study in Warsaw. And even though the WSL was a joint creation of philosophers and mathematicians, logic - as a subject of its research - was not regarded as a part of mathematics or philosophy, but as an autonomous science.

Well-known representatives of WSL (in alphabetical order) were: Stanisław Jaśkowski (1906-1965), Adolf Lindenbaum (1904-1941?), Andrzej Mostowski (1913 -1975), Moses Presburger (1904?-1943), Jerzy Słupecki (1904-1987), Bolesław Sobociński (1904-1980), Czesław Lejewski (1913-2001) and Mordechaj Wajsberg (1902-1942?). Most were mathematicians, with the exception of Sobocinski, who graduated in philosophy, and Lejewski, who studied classical philology.

In the WSL, unprecedented results were achieved. Heinrich Scholz from Münster said:

Warsaw became the main centre of logical studies.

Thus, in the lifetime of one generation, Polish logic grew from ground level to the acme of international acclaim. In the well-known book of A. Fraenkel, Y. Bar-Hillel, and A. Levy [5, p. 200], it is stated that: 
Probably no other country, taking into account the size of its population, has contributed so greatly to the development of mathematical logic and foundations of mathematics as Poland.

and that:

this curious fact should be explained sociologically.

The masters of WSL - Leśniewski, Łukasiewicz and Tarski - were individualists with different personalities, who shaped their students in many ways. Leśniewski gave the WSL its theme of synthesis, Łukasiewicz its dynamics, and Tarski the contact with mathematics (see Woleński [21]). As Jan Woleński writes [21], there were no divisions in the School into 'old' and 'young', 'beginner' and 'advanced'. The School had a strong emphasis on cooperation, irrespective of social position, views, or character of members. Thus, it combined scientists active in public and academic life. Members also differed in socio-political and religious views, or their personalities: Łukasiewicz and Sobociński were conservatives; Lindenbaum and Presburger leaned towards communism. Some were devout Catholics, others were followers of Judaism, some were atheists. Except Leśniewski, who was quite reserved, most were persons of a rather friendly nature. Regardless of their differences, they united around a shared scientific idea, the charisma of their teachers, awareness of their exceptionality, and their position in the development of logic in the world.

The problems which the WSL dealt with belonged mostly to mathematical logic. Still, it all started in philosophy. Both Łukasiewicz and Leśniewski earned their Doctor's degrees in philosophy at the University of Lvov: the first - in 1902, and the other - in 1912; both under the supervision of Kazimierz Twardowski. Łukasiewicz started with methodology of empirical sciences. But his monograph About the Principle of Contradiction in Aristotle (published in Polish in 1910, see [11]) adds a short lecture on 'algebraic logic'. The works by Łukasiewicz, besides those of Jan Śleszyński, are the first in Poland on mathematical logic. Łukasiewicz never resumed his research into the methodology of science. Leśniewski's studies in the time before the First World War concerned primarily problems of semantics of colloquial language and antinomies.

The philosophical education of the WSL founders strongly influenced their disciples and their output in mathematical logic inducing great care for intuitive value. The representatives of the WSL connected philosophical questions to those of formal logic, solving classical problems of philosophy by its means. For instance, Eukasiewicz was convinced that the three-valued logic he had created in 1920 (see [12]) indeed cast new light on the problem of determinism. And of course, in the famous work [18] (see [19]) on the concept of truth (published in Polish in 1933 and translated into many languages), Tarski solved one of the fundamental questions of the theory of knowledge in such an undisputable manner that probably no other account could claim. As to the self-image, Leśniewski called himself a 'philosopher-apostate', while Łukasiewicz considered himself a philosopher. Still, 
Łukasiewicz also did purely formal work, while to Leśniewski logic was always a tool for philosophical questions.

Another feature of the WSL was a drive for full, precise and simplest solutions to problems. This 'perfectionism' (Łukasiewicz) caused the Warsaw logicians to often release results with a delay, even at the risk of losing priority. They delighted in formally perfecting systems, simplifying axioms several times. A peak achievement was reduction of axioms to only one, as short as possible in terms of symbols. The most surprising results in this area were achieved by Łukasiewicz and Sobociński, and it is worth recalling that Łukasiewicz and Leśniewski created two types of original and inventive logical symbolism.

We will not describe concrete achievements in detail, since there are many sources. A core subject in the WSL was methodology of the propositional calculus, initiated by Łukasiewicz. Tarski's results on the notion of truth are the most outstanding. Famous other contributions were by Lindenbaum, Wajsberg on intuitionism, or Jaśkowski's natural deduction system. Tarski's subsequent accomplishments extended to the methodology of all deductive systems. Starting from 1930, he initiated the abstract study of axiomatic systems, but also a standard semantic viewpoint in his paper on the notion of truth $[18,19]$. Tarski led a very busy didactic activity, and his students who obtained outstanding results already before the World War 2 included Andrzej Mostowski and Wanda Szmielew.

A highly original strand in the Warsaw School was Leśniewski's creation of the systems of 'prototetics', 'ontology' and 'mereology' in 1929-30 (see [8, 9]), trying to improve on the mathematical foundations of Russell and Whitehead. Especially, Leśniewski's ontology has continued to attract interest, for instance from Jerzy Słupecki, Andrzej Grzegorczyk and Bar-Hillel, and in the early 1970s Boguslaw Iwanuś. But perhaps his most famous system is the mereology, studied by Tarski and many others, that still finds applications in geometry, biology, and linguistics today.

The notion of a scientific school is a complex one. Members should address a common problem with shared methods of investigation. The WSL satisfied this to a high degree. Also, a true school should have results that create a valuable whole.

What was the lasting contribution of the WSL? The 400-page volume Polish Logic 1920-1939 (edited by S. McCall [16] in 1967), which has translations of 17 articles by Polish logicians. All, except two, are from the WSL. Also, during that period, the Selected Works of Lukasiewicz [14] and [15] appeared; the first edited by J. Słupecki, the second by L. Borkowski. Half of them were papers from the interwar period. Also there was a monograph by E.C. Luschei on The Logical Systems of Leśniewski [10]. A wide selection of Tarski's pre-war articles was Logic, Semantics, Mathematics [19].

A scientific school should also be characterized by personal contacts of its members, an atmosphere of constant discussion and exchange of thoughts. The following excerpt from Eukasiewicz's preface to his Elements of Mathematical Logic [13] illustrates what the cooperation at Warsaw University looked like: 
I owe the most to the scientific atmosphere created at Warsaw University in the field of mathematical logic. It is in discussions with my colleagues, mainly Professor Leśniewski and Assistant Professor Tarski, and often also with students of theirs and mine that I had a chance to comprehend many a notion, absorb new ways of expressing myself, and learning many a new result whatever their authors were like.

The second period of the L-WS was a phase of splendid creative prosperity: talents that crystalized during the first period brought results in the form of original scientific work - ideas, conceptions and scientific systems. It needs to be emphasized that the L-WS, although known first of all for its achievements in the field of logic, presented a most pluralistic character with regards to interests and views.

\subsection{The War and Post-War Period}

1.3.1. 1939 is regarded as the last year of the WSL. Twardowski and Leśniewski died before 1939. The invasion of Poland by Germany on 1 September 1939 and by the Soviet Union on 17 September 1939 began the Second World War. Poland was again divided, under the Nazi-Soviet pact of 23 August 1939. Warsaw was completely destroyed. Many key members of the L-WS were forced to leave Warsaw.
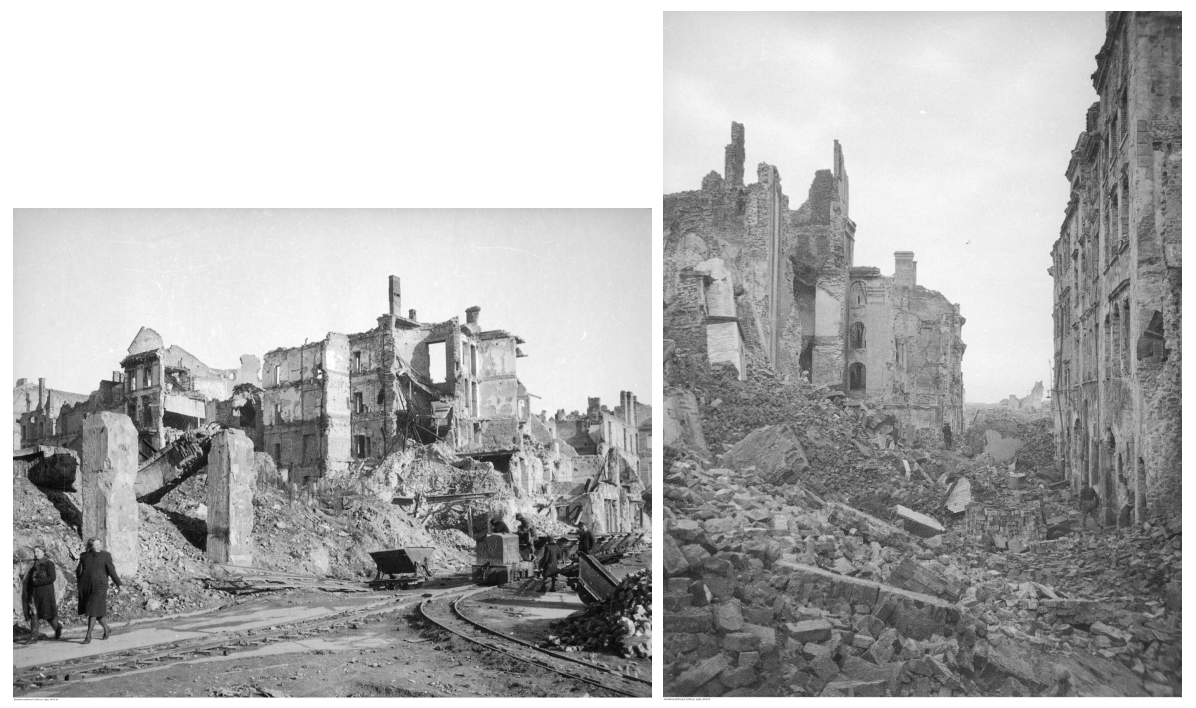

FiguRE 4. Warsaw after bombardment.

A period of unprecedented persecution and extermination of Polish citizens (especially Polish Jews) began, as well as pillage on a massive scale. Most people mentioned above lost their lives: the Lindenbaums, Presburger, Salamucha, Schmierer and Wajsberg. The Polish Government-in-Exile was constituted. 
Numerous representatives of the L-WS mentioned above emigrated from Poland during the Second World War or shortly after it: Łukasiewicz (Dublin), Tarski (Berkeley), Lejewski (Manchester), Mehlberg (Toronto, Chicago), Sobociński (Notre Dame), Wundeheiler (New York), Bocheński (Fribourge) and Poznański (Jerusalem, before 1939). Zawirski died in 1947.

On the home front in Poland itself, the resistance movement gradually evolved into an Underground State. Although teaching was conducted in secret, still scientific and cultural activity was interrupted.

1.3.2. Polish Logic after the Second World War, since 1945, never regained the renown of the WSL, not so much by losses in human resources as in rhythms of scientific activity, and losses to libraries and manuscripts. The new academic life, and lack of freedom in expressing thoughts, did not favor logic either. Lvov found itself outside Poland (it has been in the Ukraine since the War). Polish country was exposed to the darkest many years of communist terror. In the new political situation many scholars of the L-WS continued teaching and working.

Philosophers and logicians from Warsaw who did not leave Poland, went elsewhere. For instance, Stanisław Jaśkowski found himself in Torun (the city of Nicholas Copernicus) in 1945, continuing his scientific and didactic activity in logic, but also general mathematics.

Jerzy Słupecki was a typical illustration of how the Warsaw School spread in new ways. After the War, he found himself in Lublin and then in Wrocław (1948). Wrocław was then the home of displaced people from all over Poland, and expatriates from Lvov. ${ }^{3}$

Słupecki as his main scientific goal chose to continue, popularize and extend the studies of the WSL (in particular the outputs of Eukasiewicz, Tarski and Leśniewski). Słupecki also started working for the Opole Teacher's Training College, $80 \mathrm{~km}$ to the east of Wrocław, where he founded his own center of logic.

But after the War, a new Warsaw center of mathematical logic and foundations was started by Andrzej Mostowski, who stayed in Warsaw at the time when the situation of logic was difficult.

Mostowski kept close contacts with mathematicians like Kazimierz Kuratowski and Wacław Sierpiński. Continuing Tarski's work, his center studied set theory, model theory, decidability, algebraic and topological methods in logic. One persistent topic in his center has been generalized quantifiers, introduced by him in 1957 [17]. Famous names from this center are Helena Rasiowa (1917-1994) and Andrzej Grzegorczyk (1922-2014), who continued - he is deceased the pre-war traditions as a logician, mathematician, philosopher and ethicist.

\footnotetext{
${ }^{3} \mathrm{~A}$ strong group of logicians and philosophers gathered in Wrocław: mathematicians, philosophers and logicians. After the War, Wrocław became perhaps one of the leading mathematical and logical centers in Poland; two famous names are Czesław Ryll-Nardzewski and Jerzy Loś prominent logicians and mathematicians.
} 
Mostowski and Rasiowa educated a numerous group of logicians and mathematicians, who are classified to a new generation of the L-WS, and who kept up its renown.

Polish logic after the Second World War owed much to Tadeusz Kotarbiński and Kazimierz Ajdukiewicz, who still taught actively. Kotarbiński's work initiated the new discipline - praxeology. Ajdukiewicz's early ideas opened a way to study questions and answers in modern logic [1], the categorial grammar [4], and the notion of meaning $[2,3]$. It should be added that in 1955 Ajdukiewicz founded the journal Studia Logica; Studia Logica is now a significant international journal (incidentally, one of many founded by Polish logicians before the War).

The figures of the Warsaw post-war logic should also include Roman Suszko (1919-1978) - a logician and philosopher (a disciple of Zawirski and Ajdukiewicz) who, together with Ryszard Wójcicki, created in the late 1960s an active logical center at Polish Academy of Science.

1.3.3. Polish logic and philosophy still function with vigor today. We have already mentioned the strong ongoing tradition of mathematical logic, emanating eventually from the WSL described in the above. As for formal and philosophical logic, a continued influence of the L-WS is described by Jacek Jadacki in the book [7] edited by himself and by Jacek Paśniczek.

It should also be mentioned here that many Polish logicians of the new generation found a new scope for their talents, namely, in the field of computer science (that did not exist at all in the pre-War period) and many of them are internationally famous.

\section{On the Structure and Contents of the Anthology}

The book is divided into three parts related to each other. After Introduction the next three parts are in accordance with Sections 1.1-1.3. Thus, the main contents of the anthology are included into the following parts:

Part I Twardowski's School. The Period of Crystallization of L-WS,

Part II Warsaw School of Logic, its Main Figures and Ideas. The Period of Prosperity,

Part III The War and Post-War Period.

Every part consists of biographies of almost all the leaders of the L-WS, mentioned in particular sections, respectively. They will be followed most often by articles related to their outputs. All the biographies and articles were elaborated by Polish and foreign experts on the achievements of the L-WS representatives.

In Part II we omit biographies of Łukasiewicz and Leśniewski - the founders of Warsaw School of Logic - which are presented in Part I. 


\section{Acknowledgment}

First of all, the editors would like to thank Professors Jacek J. Jadacki, Jan Woleński and Andrzej Skowron for their kind support and advice, which helped to give the anthology its present form. We would like to express our utmost gratitude to all the authors of this volume, who belong to a new generation of L-WS, for their input and unrelenting efforts to accomplish sometimes very demanding tasks. Their contributions will certainly help to preserve the history of Lvov-Warsaw School for future generations.

Individual thanks are due to Iwona Bajek for the English-language verification of a number of texts in this book, and Dr. Zbigniew Bonikowski for the preparation of many works for publication in LaTeX and the style of Springer.

\section{References}

[1] Ajdukiewicz, K.: Analiza semantyczna zdania pytajnego [A Semantic Analysis of a Question Sentence]. Ruch Filozoficzny X, 194-195 (1926)

[2] Ajdukiewicz, K.: O znaczeniu wyrażeń [On meaning of expressions]. In: Księga Pamiątkowa Polskiego Towarzystwa Filozoficznego we Lwowie, Lvov (1931)

[3] Ajdukiewicz, K.: Sprache und Sinn. Erkenntnis IV, 100-138 (1934)

[4] Ajdukiewicz, K.: Die syntaktische Konnexität. Studia Philosophica 1, 1-27 (1935). English translation: Syntactic Connection. In: [16], pp. 202-231 (1967)

[5] Fraenkel, A., Bar-Hillel, Y., Levy, A.: Foundations of Set Theory. NorthHolland Publishing, Amsterdam (1958)

[6] Jadacki, J.: Polish Analytical Philosophy. Semper, Warsaw (2009)

[7] Jadacki, J., Paśniczek, J. (eds.): The Lvov-Warsaw School - the New Generation. Poznań Studies in the Philosophy of Sciences and Humanities 89. Rodopi, Amsterdam/New York (2006)

[8] Leśniewski, S.: Grundzüge eines neuen Systems der Grundlagen der Mathematik. Fundamenta Mathematicae 14, 1-81 (1929)

[9] Leśniewski, S.: Über die Grundlagen der Ontologie. Comptesrendus des séances de la Société des Sciences et des Lettres de Varsovie, Classe II 23, 111-132 (1930)

[10] Luschei E.C.: The Logical Systems of Leśniewski. North-Holland Publishing, Amsterdam (1962)

[11] Łukasiewicz, J.: O zasadzie sprzeczności u Arystotelesa. Studium krytyczne [About the Principle of Contradiction in Aristotle. Critical study]. PAU, Kraków (1910)

[12] Łukasiewicz, J.: O logice trójwartościowej [About the three-valued logic]. Ruch Filozoficzny 5, 169-171 (1920)

[13] Eukasiewicz, J.: Elementy logiki matematycznej [Elements of Mathematical Logic], M. Presburger (ed.). Nakładem Komisji Wydawniczej Koła Matematyczno-Fizycznego Słuchaczów Uniwersytetu Warszawskiego, Warszawa (1929); second edition: PWN, Warszawa (1958) 
[14] Eukasiewicz, J.: Z zagadnień logiki i filozofii. Pisma wybrane [From Issues of Logic and Philosophy. Selected Works] Selection, introduction and notes by J. Słupecki. PWN, Warszawa (1961)

[15] Łukasiewicz, J.: Selected Works. Borkowski L. (ed.). North-Holland Publishing, Amsterdam (1970)

[16] McCall, S. (ed.): Polish Logic in 1920-1939. Clarendon Press, Oxford (1967)

[17] Mostowski, A.: On a generalization of quantifiers. Fundamenta Mathematicae XLIV, 12-36 (1957)

[18] Tarski, A.: Pojęcie prawdy w językach nauk dedukcyjnych [The Concept of Truth in Languages of Deductive Sciences]. Towarzystwo Naukowe Warszawskie, Warszawa (1933); German version: Der Warhheitsbegriff in den formalisierten Sprachen. Studia Philosophica I, 261-405 (1936); English translation: The Concept of Truth in Formalized Languages. In [19], pp. 151-278

[19] Tarski, A.: Logic, Semantics, Metamathematics: Papers from 1926 to1938 (trans. Woodger J.H.). Clarendon Press, Oxford (1956); second edition edited and introduced by John Corcoran, Hackett Publishing Company, Indianapolis, Indiana, (1983)

[20] Woleński, J.: Lvov-Warsaw School. In: Zalta, E.N. (ed.) The Stanford Encyclopedia of Philosophy (Winter 2015 Edition). https://plato.stanford. edu/archives/win2015/entries/lvov-warsaw/

[21] Woleński, J.: Logic and Philosophy in the Lvov-Warsaw School. Kluwer Academic Publishers, Dordrecht (1989)

[22] Woleński, J.: Logic and the Foundations of Mathematics in Lvov. Banach Center Publications 87(1), 27-44 (2009)

[23] Wybraniec-Skardowska, U.: Polish Logic, some lines from a personal perspective. Publications of Institute for Logic, Language and Computation, Amsterdam (2009)

Urszula Wybraniec-Skardowska

Cardinal Stefan Wyszyński University in Warsaw

Department of Philosophy

Warsaw, Poland

e-mail: skardowska@gmail.com 